\title{
A BRIEF SKETCH OF THE HISTORY OF THE AMERICAN SOCIETY FOR CLINICAL INVESTIGATION
}

\author{
ASSEMBLED FROM ITS RECORDS BY \\ J. HAROLD AUSTIN, M.D. \\ (The William Pepper Laboratory of Clinical Medicine of the University of Pennsylvania)
}

The American Society for Clinical Investigation as it is now known was organized in 1908 under the name: The American Society for the Advancement of Clinical Investigation. The present name was adopted in 1916.

The story of its organization has been preserved for us by Dr. Henry A. Christian in the opening pages of the first Minute Book.

\section{FROM THE FIRST MINUTES OF THE SOCIETY}

"At the time of the meeting of the American Medical Association at Atlantic City in June, 1907, several men met in an informal conference to discuss the advisability of the organization of a society whose prime purpose should be the encouragement of medical research in this country by men engaged actively in the practice of medicine.

"As a result of this meeting a committee was organized which met at the University Club in Boston on June 17, 1907, with Dr. D. L. Edsall of Philadelphia and Drs. Wilder Tileston, J. H. Pratt, and H. A. Christian of Boston present. The general scope of the society was discussed at this time and it was decided to include in the committee Dr. W. T. Longcope of Philadelphia, Dr. Rufus Cole of Baltimore and Dr. S. J. Meltzer of New York, all of whom had been present at some of the informal discussions at Atlantic City. It was decided that a meeting should be held in New York City before the meeting of the Interurban Clinical Club for further consideration of the advisability of the organization of such a society, and before this meeting was held the committee was increased by the addition of Dr. J. A. Capps of Chicago and Dr. A. W. Hewlett of San Francisco. The names of a number of men considered eligible for membership in the society were divided between the members of the committee in order that a list of their publications during the past five years might be looked up and thus form the basis of determination of their suitableness to be asked to take part in the organization of the society. It was agreed that seven of the nine members of the committee must approve each man before he could be considered eligible to receive a notice explaining the aims and objects of the society and inviting him to be present at the meeting for organization.

"On November 7, 1907, a second meeting of the committee was held at the Manhattan Hotel, New York, with Drs. Meltzer, Edsall, Cole, Capps, Pratt, Longcope, Tileston and Christian present. It was decided to have the organization meeting of the society on the day previous to the meeting of the Association of American Physicians in Washington. A committee of three to draft a constitution for presentation at the meeting of organization was appointed as follows-Dr. W. T. Longcope, Dr. S. J. Meltzer and Dr. H. A. Christian.

$$
\begin{gathered}
\text { New Willard Hotel, Washington, D. C. } \\
\text { May 11, } 1908
\end{gathered}
$$

"At 3:30 p.m. the following gentlemen: Drs. D. L. Edsall, S. J. Meltzer, A. W. Hewlett, Wilder Tileston, E. Libman, J. A. Capps, T. C. Janeway, W. J. Calvert, J. L. Miller, J. Sailer, Martin Fischer, E. A. Locke, and Mark Richardson, met in response to a letter of invitation sent out by a committee composed of the following: D. L. Edsall, H. A. Christian, S. J. Meltzer, J. H. Pratt, W. T. Longcope, Rufus Cole, Wilder Tileston, J. A. Capps, and A. W. Hewlett, for the organization of a new society whose proposed scope had been outlined in a circular letter.

This meeting was called to order by Dr. D. L. Edsall of Philadelphia.

"Dr. Edsall was then elected temporary chairman; Dr. H. A. Christian of Boston, temporary secretary.

"The meeting proceeded to the consideration of the Constitution prepared by its committee, and with a few modifications of this adopted it as the original Constitution. Officers and Council to serve through the first Annual Meeting were elected.

"The charter members were:

Ashford, B. K., U. S. Army Baldwin, E. R., Saranac Lake Calvert, W. J., Columbia, Mo. Capps, J. A., Chicago Christian, H. A., Boston Cole, Rufus, Baltimore Cowie, D. M., Ann Arbor Edsall, D. L., Philadelphia Emerson, C. P., Baltimore Emerson, Haven, New York Fischer, Martin, San Francisco Foster, N. B., New York Hewlett, A. W., San Francisco Howland, John, New York Hunt, J. R., New York Janeway, T. C., New York Libman, E., New York Locke, E. A., Boston Longcope, W. T., Philadelphia McCarthy, D. J., Philadelphia 
Meltzer, S. J., New York

Musgrave, W. E., Manila, P. I.

Pratt, J. H., Boston

Richardson, M. W., Boston

Rosenow, E. C., Chicago

Sailer, J., Philadelphia

Simon, Charles E., Baltimore

Steele, J. D., Philadelphia

Strong, R. P., Manila, P. I.

Tileston, Wilder, Boston

Wallace, G. B., New York."

The Constitution with its eight amendments is given here, for in the printed copies only the Constitution as amended up to 1916 is to be found so that the early form tends to be lost from sight. The first printed copy in 1916 substituted the first three amendments adopted in 1911, 1913 and 1916, respectively, for the original form of these parts.

When in 1924 the next amendment was adopted it was designated as Amendment I and subsequent amendments have been successively numbered. It was probably forgotten that three prior amendments had been made.

\section{THE AMERICAN SOCIETY FOR CLINICAL INVESTIGATION CONSTITUTION}

ARTICLE I. NAME

The name of this organization shall be "The American Society for the Advancement of Clinical Investigation."

[See Amendment (1916).]

ARTICLE II. OBJECTS

The objects of this Society shall be the cultivation of clinical research by the methods of the natural sciences; the unification of science and practice of medicine; the encouragement of scientific investigation by the practitioner and the diffusion of a scientific spirit among its members.

ARTICLE III. MEMBERSHIP

\section{Section 1. Eligibility.}

Any practicing physician residing in the United States or Canada who has accomplished a meritorious, original investigation in the clinical or allied sciences of medicine, and who enjoys an unimpeachable moral standing in the medical profession, is eligible to membership.

\section{Section 2. Obligations.}

Members must manifest a continuous interest in the objects of the Society (1) by carrying out and reporting some original investigation in medicine at least once in three years; (2) by attending at least every other annual meeting. The neglect of either of these two obligations without an explanation acceptable to the Council carries with it forfeiture of membership. (3) By being active in the diffusion of the principles of the Society, particularly among the students who come under their charge.

[See Amendment IV (1939).]

\section{Section 3. Nominations and elections.}

Nominations to membership signed by two members who are not officers of the Society must be made in writing at an annual meeting of the Society, and within three months after the time of nomination the nominators shall transmit to the Council letters stating the qualifications of the nominee and also a list of his professional positions and publications. The Council shall report those nominations which are approved by a two-thirds vote to the next annual meeting for election. An affirmative vote of three-fourths of the members present shall be necessary for the election of members.

[See Amendment (1913-15).]

Section 4. Expulsion.

Members may be expelled also for reasons not especially mentioned in the Constitution by a threefourths vote of the total membership. The vote shall be by secret ballot.

[See Amendments I(1924), II(1929), III(1930), V(1941).]

ARTICLE IV. OFFICERS

Officers of the Society shall be a President, VicePresident, Secretary, and Treasurer, all to be elected as follows : each year a Councillor shall be elected to serve three years. However, at the first meeting three Councillors shall be elected, one of whom shall serve one year, one two years and one three years. The order of retirement of the first Councillors is to be determined by lot. A retiring officer, with the exception of the VicePresident, the Secretary and the Treasurer, shall not be eligible for any office until the expiration of one year. These officers are to be nominated by a committee of three appointed by the President, and the election shall be by secret ballot.

[See Amendment (1911).] 


\section{ARTICLE V. DUTY OF OFFICERS}

The duties of President, Vice-President, Secretary, and Treasurer shall be those usually assigned to those officers. The Secretary shall also arrange for the publication of abstracts of papers presented at the meetings of the Society.

ARTICLE VI. COUNCIL

Council shall consist of the President, VicePresident, Secretary, Treasurer, and the three Councillors. Four members shall constitute a quorum. It shall be the duty of the Council to supervise the affairs of the Society, to make all the arrangements for the annual meeting, to report on the work of the members, to consider all nominations for membership and to report on them at the meeting at which they shall be balloted on.

\section{ARTICLE VII. MEETINGS}

The Society shall hold one general meeting annually.

ARTICLE VIII. QUORUM

Any number of members at the appointed time of the annual meeting shall constitute a quorum for the transaction of ordinary business. For the election of members, fifteen shall be necessary for a quorum, and for altering the Constitution forty per cent of the membership shall be necessary.

ARTIClE IX. ANNUAL DUES

The annual dues of the Society shall be such sum as the Council from time to time may fix. The non-payment of dues for three consecutive years carries with it the forfeiture of membership.

ARTICLE $X$. AMENDMENTS TO THE CONSTITUTION

Amendments to the Constitution must be proposed in writing by five members at an annual meeting, and must be acted upon at the succeeding annual meeting, notices of which shall contain an announcement of the proposed amendment, and such amendments shall require for their adoption an affirmative vote of three-fourths of those present.

\section{AMENDMENTS}

1911: Article IV amended to read:

ARTICLE IV. OFFICERS

Officers of the Society shall be a President, Vice-President, Secretary, and Treasurer, all to be elected annually. In addition each year a Councillor shall be elected to serve three years.
However, at the first meeting three Councillors shall be elected, one of whom shall serve one year, one two years, and one three years. The order of retirement of the first Councillors is to be determined by lot. All officers are ineligible for re-election except the Secretary and Treasurer, who may be re-elected twice, the total period of continuous service not to exceed three years. These officers are to be nominated by a committee of three appointed by the President, and the election shall be by secret ballot.

1913 (with confirmation 1915): Article III, Section 3, to read :

Section 3. Nominations and election.

Nominations to membership may be made in writing to the Secretary at any time. Nominations must be signed by two members, who are not officers of the Society, and must be accompanied by a statement of the qualifications of the nominee and a list of his professional positions and publications. All names thus placed in nomination prior to January 1st preceding each annual meeting shall be considered by the Council, which shall pass upon the qualifications of the candidates and report to the Society for election at the annual meeting such names as it shall approve by a twothirds vote. An affirmative vote of at least threefourths of the members present shall be necessary for election.

The Council shall also report to the Society a list of candidates whose names shall be continued in nomination.

1916: Article I amended to read:

ARTICLE I. NAME

The name of the Society shall be "The American Society for Clinical Investigation."

1924: Amendment "I": add to Article III :

That the number of active members be limited to 200. Active members whose membership has extended throughout twenty years, will automatically be transferred to emeritus membership, and those whose membership has extended throughout ten years or more may at their own request be 
transferred by the Council to emeritus membership.

[See Amendments III (1930) and V (1941).]

1929: Amendment "II": add to Article III :

In addition to the classes of membership already provided, there shall be a class of associate memberships each open upon recommendation of the Council to universities, to clinics or to other organized groups and each to continue from year to year by the approval of the Council. The dues of such memberships are to be such sums as the Council from time to time may fix and these dues shall be used for the support of the Journal of Clinical Investigation. Such memberships shall be without voting privilege.

1930: Amendment “III": amending Amendment I (1924) adding:

Active members who have reached the age of forty-five years prior to the annual spring meeting of the Society, shall automatically become emeritus members.

1939: Amendment "IV": amending Article III, Section 2, to read :

Section 2. Obligations.

Members must manifest a continuous interest in the objects of the Society by the following: (1) They must attend at least every other annual meeting. The neglect of this obligation without an explanation acceptable to the Council carries with it forfeiture of membership. (2) They must be active in the diffusion of the principles of the Society, particularly among the students under their charge.

1941 : Amendment " $\mathrm{V}$ ": amending Amendment I (1924) :

(a) Active members, whose membership has extended throughout twenty years, will automatically be transferred to emeritus membership, and those whose membership has extended through ten or more years may at their own request be transferred by the Council to emeritus membership. [See also Amendment III (1930).]
Emeritus members shall be entitled to attend all meetings, but not to vote or hold office. They shall be exempt from dues.

(b) The Council shall have authority to recommend each year to the Society the names of properly qualified candidates equal to the number of retiring active members, or up to the number of twenty-five, depending on which number is the larger.

At the first Annual Meeting in Washington in 1909 there were 15 of the 31 charter members present. On the program were listed 16 papers including the President's address: of these 13 are recorded as having been read.

At this meeting the first President, Dr. S. J. Meltzer, outlined in his opening address the purposes for which the Society was formed. No better statement can be made than this address provides. It can be read in full in the Journal of the American Medical Association. Excerpts from it are presented here:

EXCERPTS FROM THE PRESIDENTIAL ADDRESS AT THE

FIRST ANNUAL MEETING OF THE AMERICAN

SOCIETY FOR THE ADVANCEMENT OF CLIN-

ICAL INVESTIGATION, MAY 10, 1909, WASHINGTON, D. C.

(From J. A. M. A., 1909, 53, 508-512)

"The honor of the presidency of a society goes with the privilege of discussing some of the aims of that society. Such a privilege becomes a duty on the occasion of its first birthday. We have to show the specificity of our objects to justify the addition of a new medical society to the many already in existence. As your first president and as one of the instigators of the movement which led to the formation of this association permit me to discuss some of the problems to the solution of which this association wishes and hopes to contribute.

CLINICAL MEDICINE AS A SCIENCE

"In the first place, I wish to discuss the problem of clinical medicine as a science. In years gone by, medicine was a unit and its leaders tried to master all its aspects. With the development of scientific methods and the growth of knowledge a process of differentiation took place. Heavy branches grew out of the stem of medicine, broke off and obtained an independent existence. Anatomy with all its dependencies broke away early, then followed physiology, pathologic anatomy, pharmacology and physiologic chemistry. Bacteriology tore off the branches of etiology and established itself as an independent growth. All these offsprings of medicine are 
now well established as pure sciences, they still closely affiliate with the mother-stem and are often designated as the sciences of medicine. What is left of the old stem is clinical medicine. What is the character of this residuum? It is generally designated as the practice of medicine. I am not aware that any one has had the courage to call it a pure science. Those who do not like to call it an art say that it is an applied science. According to this view, the relation of clinical medicine to the sciences of medicine is that of technology to science in general. I am afraid that this conception of clinical medicine is widespread among those who are in the practice as well as among those who are in the sciences of medicine.

"However this may be, I feel sure that such a view is logically erroneous and practically harmful. I wish to plead for an extension of the process of differentiation also to clinical medicine. I am of the opinion that clinical medicine as it exists now is made up of two constituents: one part has all the elements of a pure science and ought to be coordinate to the other pure sciences of medicine, and the other part is the real practice of medicine, an applied science which has many elements of an art. At present both parts are so closely interwoven that they present the appearance of a natural unit the splitting of which into two parts might appear to some as an impossible and undesirable process."

"To clinical medicine is left the study of the phenomena and their sequence as they occur in a living body during the entire course of a disease. It has to interpret these phenomena by known physiologic laws, to identify them with similar phenomena experimentally produced in animals and it has to correlate the phenomena observed in the course of a certain disease during life with the anatomic changes found at the postmortem examinations in case the disease has a fatal termination. It is also one of the tasks of clinical medicine to study the influence on the onset and course of phenomena of diseases which certain means and remedies may exert whose physiologic actions are well established. In other words, the domain of clinical research comprises the study of the natural history of diseases, their physiology and their pharmacology. Can there be any doubt that these studies constitute legitimate objects of a pure science?"

"After showing that there is a definite field for a science of clinical medicine the next question is who should be the men to carry on the research in this field? What should be their qualifications? In the first place, they must have a training fitting them to carry out investigations in conformity with the requirements existing in all pure sciences. They must not only be informed and trained in the other sciences of medicine, but must have carried on various investigations in one or more of these pure sciences, so as to become familiar with careful scientific methods and imbued with a scientific spirit. They will thus learn best how to shape a problem so as to make it amenable to a solution; how to marshall the consecutive steps of an investigation so as to bring out the reply to the question in hand. They will learn to avoid bias in the search, to apply criticism to the findings; they will learn not to trust only few facts, not to rejoice prematurely over findings and not to be disheartened by failures. They will thus acquire the habits and the tastes of the investigator, the scientist, which may then stick to them for life.

"However, after all these preparations they must select clinical research as the main field of their scientific activity. Clinical science will not thrive through chance investigations by friendly neighbors from the adjoining practical and scientific domains. Such volunteer service which for the present is keeping up the cultivation of the unacclaimed region is most certainly very welcome. But the acclamation, cultivation and maintenance of a field of pure science of clinical medicine cannot be accomplished by chance services from volunteers; for such a purpose we need the service of a standing army of regulars. The investigator in clinical science must devote the best part of his time and intellectual energies to the cultivation and elevation of this field just as the physiologist does in his domain-or at least as he ought to do."

"Let me recapitulate. There is a necessity for a differentiation of clinical medicine into a science and a practice. The clinical science has well-defined objects and is a most important department. It must be managed by a set of men specially trained for and almost exclusively devoted to that task. Without the development of such a department of clinical science the efficiency of the practice of internal medicine will lag behind, no matter how progressive the allied sciences of medicine are and how great their efforts to be useful to medicine may be.

\section{THE CONDITIONS AS THEY ACTUALLY EXIST}

"In conjunction with the foregoing considerations let me glance at the conditions of clinical medicine as they actually exist here and abroad. I may state that neither abroad nor here do we find a separate class of investigators confining their activity solely to the domain of the science of clinical medicine. Everywhere science and practice of clinical medicine go hand in hand. We may, however, admit at the outset that there is an enormous difference in the status of medical research between abroad and here. Let us take the development and the present status of clinical medicine of the German-speaking countries as an illustration of the conditions abroad. We shall notice that there the mother-stem of medicine managed to retain a scientific aspect despite all processes of differentiation."

"Teaching medicine and furthering its science is a very serious business which ought to be carried on by men who are ready to devote all or most of their time to it.

"Here are problems for you to solve. The progress of clinical medicine in this country has to be accelerated again. We might reach the level which we have seen 
to exist abroad. But we ought to strive to get still higher; in this field lack of modesty is a stimulating virtue. Look at the allied sciences of medicine, the level which they have reached in a comparatively short time without any tradition and only through the activity of a small group of high-minded men. The progress of medicine in this country was always carried on by the few and not by the masses. Clinical medicine must reclaim some of the brainy young men who were enticed by the sciences of medicine. You represent a new generation. You have had an education and a training in modern medicine and the allied sciences. You have a training in investigation, the constitution requires it of you. The constitution which you have adopted shows your spirit. Among its objects is 'the cultivation of clinical research by the methods of the natural sciences and the diffusion of a scientific spirit among its members.' But you will accomplish more; the constitution imposes on you the obligation to be active in the diffusion of the principles of the Society particularly among the students who come under your charge. I would recall this obligation to the minds of the members who were called within this year to chairs of medicine at influential places. The constitution does not keep you down exclusively to science, but let me tell you: beware of practice. It is a bewitching graveyard in which many a brain has been buried alive with no other compensation than a gilded tombstone."

The growth of the Society was rapid. In 1914 there were more than 70 members. Of these, 41 were at the meeting and 25 papers were read.

Steps had to be taken at that meeting to limit future programs to permit completion of the program in a single day.

Ever since there have been discussions as to the relative merit of a one-day meeting with a single program, a one-day meeting with simultaneous sessions in different fields of interest, and a twoday meeting. The second alternative has been used in a few meetings; but the first has been the usually favored procedure.

In 1924, to provide for the ever increasing group of young workers in the field of clinical investigation, the constitution was amended to limit active members to 200 and to transfer to emeritus status all whose membership had extended through 20 years, and to permit voluntary transfer to emeritus status after ten years of active membership.

This interesting step, so far as I know unique among our national scientific societies, has insured the persistence of an atmosphere of youthful vigor in this organization. This step was rendered easier by the custom, dating uninterruptedly from the first meeting, of holding the meetings of this society on the day preceding the meeting of the
Association of American Physicians and at the same place.

\section{The Journal of Clinical Investigation}

The Constitution of the Society provided for publication of abstracts of its papers.

Early there arose a desire to support an organ of publication which might set a high standard in the field of clinical investigation and encourage its growth.

Realization of this hope became possible when in 1923 the Rockefeller Institute offered to subsidize through its early years a journal to be owned and operated by the Society. Dr. G. Canby Robinson was selected as Editor. Six members of the Society were elected as the first Editorial Board. The formulation of general policies and the election of Editor and Editorial Board was made the responsibility of an Editorial Committee of 15 members each to serve three years; five of its members retiring each year, with the vacancies filled by elections by the Society at its annual meeting.

The first issue of The Journal of Clinical Investigation appeared in October, 1924, and subsequent numbers appeared at bimonthly intervals. Early volumes vary in the period of a year covered, for those volumes were closed whenever a prescribed quota of pages had been issued. Later the Journal's volume became identical with the issues of a calendar year.

When the subsidy from the Rockefeller Institute ceased, financial aid was given for several years by the Rockefeller Foundation. For the next few years many of the departments of medicine of our universities accepted associate memberships in the Society as a form of subsidy for the Journal.

With Volume XI in 1932 the Chemical Foundation became interested in the project through the efforts of Dr. G. Canby Robinson. It began meeting all deficits in the costs of the Journal and continued this until recently the growth of the subscription list has placed the Journal on a self-supporting basis. During the recent war the Commonwealth Fund has aided the Journal by a grant to facilitate publication of studies arising out of the problems of the war.

The editorial staff for the first few years of the Journal is not recorded in the bound files of the Journal, for this information appeared only on the 
cover pages of those issues and these pages are discarded on binding. The following tabulation has, therefore, some reason for record.

EDITORS

$\begin{array}{lcc}\text { G. C. Robinson } & \text { Editor } & 1924-1927 \\ \text { J. H. Austin } & \text { Editor } & 1927-1935 \\ \text { R. West } & \text { Associate } \\ & \text { Editor } & 1932-1935 \\ & \text { Editor } & 1935-1940 \\ \text { J. L. Gamble } & \text { Editor } & 1940-1947 \\ \text { A. M. Butler } & \text { Associate } \\ & \text { Editor } & 1940-1947 \\ \text { C. S. Keefer } & \text { Associate } \\ & \text { Editor } & 1943-1947 \\ \text { E. M. Landis } & \text { Associate } \\ & \text { Editor } & 1943-1947\end{array}$

EDITORIAL BOARD ( $\mathrm{six}$ to ten members)

$\begin{array}{ll}\text { J. H. Austin } & 1924-1927 \\ \text { A. E. Cohn } & 1924-1936 \\ \text { R. Cole } & 1924-1930 \\ \text { W. T. Longcope } & 1924-1936\end{array}$
F. W. Peabody
1924-1927
G. C. Robinson
1924-1935
R. T. Woodyatt
1924-1928
J. H. Means
1928-1931
L. H. Newburgh
1928-1930
W. S. McCann
1930-1943
C. P. Miller, Jr.
1930-1947
J. P. Peters
1931-1947
H. L. Blumgart
1933-1947
J. L. Gamble
1933-1940
T. M. Rivers
1933-1947
F. N. Wilson
1933-1940
F. G. Blake
1936-1947
R. F. Loeb
1936-1947
R. West
1940-1943

After the inauguration of the Journal the Proceedings of the meetings regularly appeared in abstract in that journal, beginning with the Seventeenth Annual Meeting in May, 1925.

The earlier Proceedings appeared in abstract as shown below and reprints were usually distributed to members.

PROCEEDINGS (IN ABSTRACT) OF THE

AMERICAN SOCIETY FOR THE ADVANCEMENT OF CLINICAL INVESTIGATION

Meeting

No. Date Place held Reprinted from

1. May 10, 1909 Washington, D. C. Boston M. \& S. J., 162, 462-467 (April 7, 1910)

(Note: President S. J. Meltzer's address is reprinted in full in J. A. M. A., 53, 508-512, Aug. 14, 1909)

2. May 2, 1910 Washington, D. C. Boston M. \& S. J., 162, 867-871 and 900-905 (1910)

3. May 8, 1911 Atlantic City, N. J. J. A. M. A., 57, 148-151 (1911)

4. May 13, 1912 Atlantic City, N. J.

5. May 5, 1913 Washington, D. C.

6. May 11, 1914 Atlantic City, N. J.

7. May 10, 1915 Washington, D. C.

J. A. M. A., 59, 137-139, 218-220 (1912)

Probably privately printed (no reprints located)

Privately printed, no place given

Privately printed, no place given

THE AMERICAN SOCIETY FOR CLINICAL INVESTIGATION

8. May 8, 1916

9. May 1, 1917

10. May 6, 1918

11. June 14, 1919

12. May 3, 1920

13. May 9, 1921

$\begin{array}{ll}\text { Atlantic City, N. J. } \\ \text { 9, } 1921 & \text { Atlantic City, N. J. }\end{array}$
Privately printed, no place given; 1916 constitution included

Probably privately printed (no reprints located)

Probably privately printed (no reprints located)

J. A. M. A., 73, 637-639, 714-715, 785-787, 860-861 (1919)

J. A. M. A., 74, 1597-1600, 1667-1669, 1737-1738, 1793-1794 (1920)

Privately printed by Press of A. M. A., Chicago

(Note: In this report, tribute is paid to Dr. Meltzer's memory by Dr. Longcope, who briefly describes how the Society came to be organized)

14. May 1, 1922 Washington, D. C. J. A. M. A., 78, 1660-1662, 1751-1754, 1838-1840, 1919-1922 (1922)

15. April 30, 1923 Atlantic City, N. J. J. A. M. A., 80, 1641-1644, 1727-1728 (1923)

16. May 5, 1924 Atlantic City, N. J. J. A. M. A., 82, 1988-1990, 2077-2078 (1924)

17, et seq.: J. Clin. Invest. 
The most complete library collection of these early Proceedings is, according to the latest Union Serials List, the New York Academy of Medicine Library, which at present has the reprints for the following meetings : $1,2,3,4,6,7,8,11,12,13$, $14,15,16$. In the same library are Lists of Members 1909, 1910, 1916 and Triennial Catalogues 1923, 1926, 1932.

So in brief is the story of the founding of our Society, of its goals and accepted functions, of its constitution gradually modified to meet the needs of the organization, and of the institution and growth of The Journal of Clinical Investigation which the enthusiasm of this young Society and the generosity of sympathetic foundations have made a realized possibility.

No one can compare the first presidential address with the record of the Society's achievements and not recognize the outstanding success with which our Society has served the purposes for which it was founded.

\section{LETTER FROM THE EDITORS}

\section{CLINICAL INVESTIGATION}

The Editors are frequently confronted with the question as to what is and what is not clinical investigation. It is true that the physician who continues to develop his clinical acuity and maturity of judgment by constant observation of the patient is employing the most ancient and still a most valuable technique of clinical investigation. A natural outgrowth of the descriptive stage of medical knowledge occurred when clinical investigation became related to morphology, with anatomy and pathology providing the foreground and background between which the patient, as an example of altered structure and function, found a somewhat uncomfortable place. With rapid advances in chemistry and physics the role of disordered function was explored by those whose main contribution was providing physical juxtaposition of patient and experimental laboratory. The paraphernalia of the laboratory with rapid multiplication of apparatus and test led to the notion that the more numerous the exact facts the better was the understanding of disease. This is true. It was forgotten, however, that abstract disease, without focus in a sick person, has no meaning.

For a time clinical investigation was carried along in the expanding domain of the laboratory and to a degree was synonymous with chemical investigation. A new test was devised and there appeared in medical journals an outpouring of reports on its application to a great miscellany of conditions. Blood levels and contents, clearance tests, tolerance tests, ph, and milliequivalent became the sine qua non. While this extension of the physical examination into the laboratory yielded a rich harvest, a tendency arose for the laboratory datum to displace other aspects of the patient from the student's attention. There were indications that study of the part might obscure the whole. The use of instruments sometimes became an object in itself and there arose the cult of the sphygmomanometer, the electrocardiogram, the electroencephalogram, the metabolism machine, and others, each eminently useful as a stepping stone to fuller knowledge of a sick person but reaching an early state of diminished returns as minutiae were explored.

This is not to decry the advances in knowledge as such, but the fact that the clinical investigator was so of ten led away from the patient because of his preoccupation with a test or an implement. This state of affairs comprises specialization and has brought benefits no one would willingly discard. The danger is that in concentrating on one aspect of disease so intensively the student risks a gain in knowledge at the sacrifice of wisdom. And the wisdom which clinical investigation should supply is to look at the sick person not as the inevitable but uninteresting vehicle of a fascinating lesion or syndrome but whole-related to external as well as internal environment. New trends in this direction are found on many sides and the recent emphasis on emotional, social and economic factors in human sickness is a healthy sign of a return to the patient as a person.

Psychosomatic medicine, a cumbersome though useful term, epitomizes this tendency. Clinical investigation must now include this broader approach in order to obtain and correlate facts from the environment as they relate to a patient and his disease. It should be remembered, however, that investigation into such problems not only is most difficult but requires maturity and a sound working knowledge of the phenomena of health and illness. Unless the method of comparison and control which has been developed in the traditional form of clinical investigation is applied in this newer area the fragmentation inherent in a new specialty may disintegrate rather than integrate our approach to disease.

Essentially, clinical investigation is the study of the sick person, his past experiences and adaptations, and their relation to his present plight as it is manifest by deviations in structure, function and behavior, and the internal and external processes upon which they depend. Orientation exclusively to either the internal or the external events of disease, or to only portions of these two major fields for clinical investigation must lead inevitably to the dissipation of our efforts to gain that true understanding upon which must be based present treatment and future prevention of the disorders which vex both the patient and his physician. 